\title{
Výuka distanční formou - e-learningové kurzy o aktuálních problémech klimatu
}

\author{
Aleš Vávra, Vilém Pechanec, Jitka Šeflová \\ Envigogika 2011/VI/1- Recenzované články/ Reviewed Papers \\ Publikováno/Published 05. 05. 2011 \\ DOI: http://dx.doi.org/10.14712/18023061.58
}

\begin{abstract}
Abstrakt:
V současné době jsou témata z oblasti klimatu velmi aktuální. Pojmy jako globální oteplování, znečištění ovzduší nebo klimatická změna jsou zmiňovány čím dál častěji. Velmi důležité je objasnění těchto i dalších problémů široké veřejnosti, zejména pak žákủm a studentům různých vzdělávacích zařizení za využití moderních přístupů.

Vytvořením e-learningových kurzů na téma klimatu a jeho změny se zabývá projekt eklima. $\vee$ rámci projektu byl vytvořen výukový model e-learningových kurzů celoživotního vzdělávání ve vybraných oblastech životního prostředí se zaměřením na klima a jeho změnu. Garanti z oblasti vysokých škol společně s odborníky na klimatologii zajištúují kvalitu a množství informací z oblasti ochrany životního prostředí v jednotlivých lekcích. Obsah e-learningových kurzů je zaměřen na tematické okruhy zahrnující fyzikální podstatu klimatu, prírodovědné aspekty klimatu, ochranu prírody, krajiny a ovzduší, ekonomiku, legislativu a politiku ochrany klimatu, prričiny a důsledky změn klimatu, apod. Jednotlivé lekce pritom neposkytují pouze strohé informace, ale jsou zde uvedeny i náměty k zamyšlení nebo návody $\mathrm{k}$ racionálnímu využívání prírodních a obnovitelných zdrojů energie. Počítačem podporovaná výuka formou e-learningu hraje $v$ celoživotním vzdělávání významnou roli, protože kromě tematicky zaměřeného obsahu kurzů se uživatel seznamuje i s počítačovým prostředím a s možnostmi internetu. Samotný kurz obsahuje kromě textových, grafických a multimediálních prvků i diskusní fóra, nápovědu, ale také odkazy na další internetové stránky a možné zdroje informací.
\end{abstract}

\section{Klíčová slova:}

Klima, e-learning, e-klima, vzdělávací portál

\begin{abstract}
:
Climate change is a topical issue discussed in varying depth and affecting everyday life and political and economic decision-making that touches everyone. It is essential to make relevant scientific information accessible to a wide, non-expert audience. Providing information about climate change to the younger generation of students is very important. One way of doing this is via e-learning - a modern form of distance learning. E-learning makes it possible to adapt education to individuals' needs, including disabled learners. Technology in support of learning enables remote communication and cooperation, can facilitate the removal of communication barriers and reduce the stress load by making study more flexible. This leads to the improved quality of the students' learning approach. The current need for modern and efficient presentation of information focused on climate
\end{abstract}


change is realized through the eklima project. The research aim is to create e-learning courses with a thematic focus on the climate and its change, consisting of up-to-date and accurate information from the field of climate change and the environment. The main objective of the courses is to provide educational materials to various groups of users (from primary schools to departmental staff offices), focusing on natural and social sciences related to the climate, climate change and other Earth sciences. The article presents the e-learning method and provides a brief evaluation of its benefits and drawbacks.

\section{Key words:}

Climate, E-learning, eklima, Education portal 


\section{Úvod}

Klima a jeho změna je aktuálním tématem, které je často diskutováno nejen ve vědeckých kruzích. Stále intenzivnější jsou debaty o klimatu především v politické a diplomatické sféře. Je nezpochybnitelné, že toto téma začíná ovlivňovat život každého člověka. A nejsou to pouze přímé dopady změn klimatu, ale hlavně politická a ekonomická opatření, která se týkají opravdu každého (van Ierland, Gusta, Kok, 2001). Poskytovat relevantní vědecké informace každému jedinci srozumitelnou cestou je tak nyní společensky nezbytné. Zejména předávání informací o klimatu a jeho změně mladé generaci, studentům, žákům a laické veřejnosti je velmi důležitým úkolem.

E-learning, stejně jako nové multimediální technologie a internet, je široce využíván ke zkvalitnění výuky a usnadnění přístupu k informačním zdrojům, a podporuje distanční metody spolupráce a komunikace (CEC, 2001). Díky e-learningu se vzdělávání přizpůsobuje jednotlivcům. Uživatelé e-learningových kurzů postupují vlastním tempem díky vzdálenému přístupu k informacím a studijním materiálům, které jsou stále častěji dostupné i v multimediální podobě. Taková podpora vzdělávání umožňuje vzdálenou komunikaci a spolupráci mezi studenty a odstranění komunikačních bariér (Nocar, 2004). To vede ke zlepšení kvality výuky žáků, studentů a dalších uživatelů. Velké množství uživatelů si díky e-learningu rozvinulo svou kreativitu, samostatné uvažování nebo schopnost zapojit se do týmové spolupráce (Noll, Wilkins, 2002). Výhodou e-learningu je i možnost kvalitní zpětné vazby ve vzdělávacích procesech, a to i $v$ celoživotním vzdělávání. Rozvoj nových metod učení, včetně e-learningu, výrazně podporuje kompetence nezbytné v informační společnosti, např. schopnost vyhledávat informace a přetvářet je ve znalosti.

\section{Klimatické změny}

Klima se mění a měnilo v celé historii vývoje Země. Změny klimatu se odehrávají v různých časových i prostorových horizontech a mají různé přičiny a různou velikost (Ghil, 2002). Proměnlivostí klimatu se vědci zabývali dlouhou dobu před tím, než se stala veřejně a politicky diskutovaným tématem. Přirozená změna klimatu byla poprvé vědecky zdokumentována na příkladu střídání ledových a meziledových obdobích pleistocénu. vývoj teorie ledových dob během 19. století umožnil objev dlouhodobých klimatických cyklư řízených astronomickými silami, který je popsán v Milankovičově teorii (Oliver, 2005).

Objev skleníkového efektu, který způsobují některé plyny v zemské atmosféře, spolu s dlouhodobým pozorováním změn teplot vzduchu a koncentrací oxidu uhličitého, vedl k hypotéze určitého působení člověka na klima. Svou činností člověk zasahuje do rưzných složek klimatického systému. Nejsou to jen emise plynů či aerosolů, ale také zásahy do vodního režimu (znečištění povrchových vod, stavba přehrad, regulace vodních toků) nebo změny povrchových charakteristik (odlesňování, zástavba, zemědělská činnost, dopravní stavby apod.). Každý z těchto zásahů může ovlivňovat klimatický systém jako celek. Dlouhodobé teplotní pozorování, sledování koncentrace oxidu uhličitého (od konce 50. let), větší znečištění ovzduší, zmenšení ozonové vrstvy nebo odlesňování vyvolalo diskuzi nad rozsahem antropogenního vlivu na klima. Pojem globální oteplování pak přitáhl pozornost celého světa, jak ve vědeckých kruzích, tak mezi politiky a širokou veřejností.

$\checkmark$ roce 1988 byl založen Mezivládní panel pro změnu klimatu (Intergovermental Panel on Climate Change - IPCC), v jehož rámci byly zahájeny mezinárodní diskuse o otázkách klimatu a jeho změn (IPCC, 2007). IPPC byl založen Světovou meteorologickou organizací (World Meteorological Organization - WMO) a Programem OSN pro životní prostředí (The United Nations Environment Programme - UNEP). Nemá žádné rozhodovací pravomoci, ale zpracovává hodnotící zprávy, které jsou významným podkladem pro smluvní strany Rámcové úmluvy OSN o klimatických změnách. Zatím byly vydány čtyři hodnotící zprávy a pátá je v př́pravě. Zde je přehled: 
1. První hodnotící zpráva (FAR) vydaná IPCC v roce 1990, sloužila jako vědecký základ pro implementaci Rámcové úmluvy OSN o změně klimatu, která vedla k dohodě známé jako Kjótský protokol (IPCC, 2007).

2. Druhá hodnotící zpráva SAR byla vydaná v roce 1995.

3. Tretí hodnotící zpráva TAR byla vydaná v roce 2001.

4. Čtvrtá hodnotící zpráva AR4 byla vydaná v roce 2007.

Čtvrtá hodnotící zpráva (AR4) popisuje podrobný soubor změn teploty, srážek, atmosférické cirkulace, zalednění, výšky hladiny moře a dalších jevů spojených se změnou klimatu na celosvětové i regionální úrovni. Důležitým výstupem zprávy AR4 bylo konstatování, že pozorovaný nárůst globální teploty je velmi pravděpodobně důsledkem pozorovaného nárůstu antropogenních emisí skleníkových plynů (IPCC, 2007).

Souhrnné výstupy z hodnotící zprávy IPCC, stejně jako další vědecké studie, byly předloženy politikưm, médiím i široké veřejnost. Klimatické změny byly zahrnuty do environmentální politiky některých států a také nastala široká debata o dopadech na socioekonomickou složku. Stále častěji jsou zmiňována témata jako udržitelný rozvoj, obchodování s emisemi, koloběh uhlíku nebo nárůst extrémních meteorologických jevů (vichřice, záplavy, sucha, vlny veder, atd.). Uváděné informace o klimatické změně jsou velmi různorodé, objevují se extrémně varovné názory, na druhé straně se popírá vliv člověka na klima. Tato rozporuplnost $v$ posledních letech názorově rozděluje společnost a nepřispívá $k$ vytvoření reálného obrazu zejména u laické veřejnosti. Souhrnné informace v podobě kurzů založených na vědeckých základech by mohly významně pomoci při pochopení problematiky klimatické změny, zejména u mladých lidí a široké veřejnosti. Pokud jsou tyto kurzy realizovány $v$ elektronické podobě, jsou snadno dostupné, srozumitelně sestavené a doplněné atraktivními multimediálními prvky, mají potenciál se stát velmi praktickou a názornou pomůckou.

\section{E-learning - výhody a nevýhody}

Lze konstatovat, že e-learning jako podpora výuky představuje pro mnohé uživatele poměrně nové možnosti, jak se vzdělávat. Raada potenciálních uživatelů nemá potřebné informace o e-learningovém vzdělávání a téměř žádné zkušenosti s ním. $Z$ toho důvodu je nutné $v$ počáteční fázi výuky studujícím názorně a pečlivě vysvětlit přednosti a výhody e-learningu. Je možné říci, že tato forma vzdělávání je vhodná i $v$ prípadě, kdy u studujících existují obavy z e-learningové podoby vzdělávání a využívání informačních a komunikačních technologií (Zlámalová, 2008). V tomto prípadě se vyžaduje u studujících větší čas na osvojení si nových technologií a na uvědomění si jejich přínosů a výhod. Pro překlenutí problému s ICT je vhodnou možností tzv. blended learning, který vyžaduje částečný osobní kontakt mezi studujícím a jeho lektorem. Lektor ve své roli kurzem studenta provází, doporučuje vhodné studijní pomůcky a kontroluje průběžný postup ve studiu. Studující má možnost kdykoli kontaktovat lektora a pokládat mu dotazy týkající se jednotlivých výukových prvků. 
Tab. 1 Výhody a nevýhody e-learningu

\begin{tabular}{|c|c|}
\hline \multicolumn{2}{|l|}{ E-learning } \\
\hline Výhody & Nevýhody \\
\hline samostudium & chybí přímý kontakt lektora se studujícími \\
\hline časová flexibilita, nižší nároky na kapacity & $\begin{array}{l}\text { vyžaduje vysoké nároky na kvalitu } \\
\text { studijních pomůcek a celkovou organizaci }\end{array}$ \\
\hline $\begin{array}{l}\text { možnost využití pro vzdělávání početné cílové } \\
\text { skupiny z rưzných oblastí }\end{array}$ & $\begin{array}{l}\text { nevhodnost pro výuku týmové práce a další } \\
\text { složitější metody či organizační formy }\end{array}$ \\
\hline $\begin{array}{l}\text { vzdělávání může být využito i pro studium } \\
\text { rozsáhlejší problematiky, ne však př́liš } \\
\text { náročné }\end{array}$ & \\
\hline
\end{tabular}

Úspěšnost e-learningových kurzů závisí také na kvalitě vytvořených studijních pomůcek a podkladů, tj. studijních interaktivních textů, příruček a manuálů, kvalitě komunikačního (webového) prostředí, organizaci a logistice kurzů. Zároveň musejí být vytvořeny kvalitní komunikační kanály mezi studujícími a případným poradcem. Logistika a organizace kurzu musí být zvláště precizní. Je potřeba vhodně stanovit termíny osobních setkání (úvodní, kontrolní, závěrečné) v kontextu pracovního režimu účastníků, $\checkmark$ materiálech specifikovat reálnou časovou náročnost a požadavky na pomůcky, termíny plnění úkolů musí zohledňovat pracovní režim studujících i případná technická omezení. Jedním z komunikačních kanálů je speciální webové rozhraní (Learning Management Systém - LMS), které poskytuje veškeré služby cílové skupině $v$ podobě aktuálních informací, studijních textů a ostatních studijních pomůcek.

Při aplikaci e-learningu do výuky však stále existuje řada bariér pro efektivnější využití výhod. Jedná se zejména o obavy a neochotu vedení školských institucí i jednotlivých pedagogů. To je nejčastěji odrazem nízké míry potřebných kompetencí učitelů i finanční nedostupnosti komerčních systémů pro řízení výuky, přestože tyto problémy Ize překonat využíváním Open Source systémů. Společným jmenovatelem výše uvedených bariér je nesprávné chápání e-learningu a obavy z odlidštění (White, Tastle, Fox, 2003). Přitom komunikace pouze mění své formy, protože $v$ době Internetu může komunikace mít široký rozsah a nabývat rozmanitých podob; navíc může být individualizovaná.

\section{Projekt "eklima"}

Potřeba rychlého a efektivního poskytnutí informací o klimatu a jeho změně je realizována prostřednictvím projektu eklima. Jako výuková podpora byl zvolen právě e-learning. Vytvářením výukového prostředí se zabývala Univerzita Palackého v Olomouci, která je i hlavním koordinátorem projektu. Kvalitní obsahovou část pojednávající o klimatu a jeho vlastnostech zaručil Český hydrometeorologický ústav. Informace o politických a ekonomických rozhodnutích a opatřeních poskytla Vysoká škola ekonomická v Praze. E-learningové kurzy jsou koncipovány jako celoživotní vzdělávání a jsou tedy zaměěeny na několik uživatelských skupin zahrnujících žáky základních, středních a vysokých škol, pracovníky resortu MŽP a orgánů státní správy, zájemce z řad široké veřejnosti. Kurzy jsou vytvořeny podle nových trendů, nejedná se pouze o obyčejný studijní text. Objevují se zde multimediální prvky jako obrázky, animace, videa, učební text je možné poslouchat ve zvukové podobě. Atraktivitu kurzu dokreslují motivační a aktivační prvky, jako hry, kvízy, týmové úkoly. Komunikační prostředí je zajištěno diskusními fóry i př́mou on-line komunikací. Ověření získaných znalostí je umožněno použitím různých druhů testových položek. Nedílnou součástí komunikačního prostředí jsou nástroje zpětné vazby (ankety, 
dotazníky) přinášející poznatky lektorům o celkové organizaci kurzu, náročnosti a struktuře studijních podkladů, a tvưrcům kurzu o funkčnosti a atraktivitě vlastního výukového prostředí.

\section{Obr. 1: Logo projektu}

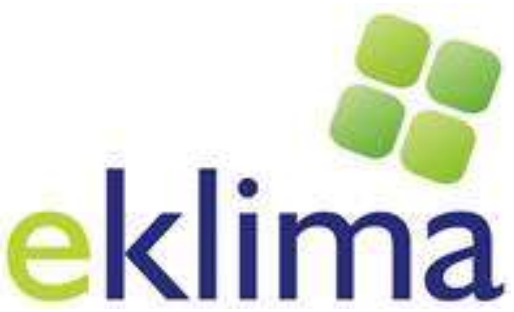

Řešení projektu bylo rozděleno do několika částí:

1. Vytvoření metodiky a tvorba výukového modelu

2. Výběr vhodného LMS (Learning Management System) jako výukové platformy

3. Stanovení obsahu kurzů a jejich naplnění

4. Pilotní testování

5. Vyhodnocení a plné spuštění e-learningových kurzů

\section{Vytvoření metodiky a tvorba výukového modelu}

Vytvoření výukového modelu pro různé cílové skupiny vychází z analýzy dostupných informací o metodách počítačem podporované výuky klimatologie, ekologie a dalších věd o Zemi na jednotlivých stupních vzdělání (od základních škol až po kurzy celoživotního vzdělávání). Zdroje informací, dat, dokumentů a poznatků byly odborně zhodnoceny a zapracovány do znalostní báze o tom, jaké informace o daném tématu a $v$ jaké podobě jsou k dispozici. Tyto informace pak mohou být použity jako odborný podklad pro následnou tvorbu kurzů. Při analýze (nejen literární, ale i datové na úrovni národních a celosvětových databází) byly evidovány následující parametry:

- Název zdroje (jméno webu, název knihy apod.)

- $\quad$ URI = Uniform resource identifier (jedinečná identifikace zdroje např. ISBN, URL)

- Dostupnost (je potřeba rozepsat dostupnost dokumentu, zda je volně přístupný nebo zda je vyžadováno heslo pro přístup)

- Datum publikování

- Klíčová slova (minimálně 5 klíčových slov)

- Stručná anotace (česky)

- Typ dokumentu (CD, pdf, článek, webová stránka, atd.) 
- Texty, obrázky (přibližný počet stran, obrázků, videa, atd.)

- Cílová skupina (pro jakou skupinu lidí je dokument určen, např. žáci ZŠ)

Důležitá byla i identifikace chyb, kterých je nutno se při tvorbě vyvarovat. Pozornost byla věnována také způsobům a možnostem využívání e-learningu a jeho uplatnění ve veřejnoprávní i soukromé sféře. Výsledkem všech analýz jsou metodiky a doporučení pro sestavení vlastního výukového modelu. Při analýzách se zohledňovala nejen uživatelská stránka, ale i aspekty vývoje. Při sestavení metodických dokumentů, jak psát jednotlivé texty (Vávra a kol, 2009), byly brány v potaz i jednotlivé uživatelské skupiny, pro které byly kurzy vytvářeny:

- S školská skupina (tři podskupiny: školy základní, střední a vysoké),

- $\quad$ resortní skupina (dvě podskupiny: odborníci v oboru pracující v resortu MŽP a zaměstnanci státní správy a samosprávy bez odborného vzdělání v oboru pracující v resortu MŽP, včetně pracovníků veřejné správy a výzkumných a poradenských institucí),

- veřejná skupina (laická veřejnost se zájmem získat více informací v daném oboru, včetně podnikatelské sféry a neziskových organizací).

Sestavování výukového modelu probíhalo $v$ několika krocích. $V$ úvodu byly jako výsledek předchozích analýz a vzájemné diskuse, zejména mezi řešiteli projektu, kteří již mají osobní zkušenost s e-learningem, sjednoceny a definovány stěžejní pojmy (např. výukový model, modul, kapitola, cílová skupina atd.), a pro ně zpracovány teoretické podklady.

E-learningový nástroj je efektivní pouze tehdy, pokud má pečlivě připravenou a optimálně sestavenou strukturu a design výukového modelu (Nichols, 2003). Proto klíčovým úkolem při sestavení kurzu je vytvoření vhodného výukového modelu, jeho struktury a prvků. Stanovuje se počet modulů, které bude kurz obsahovat, dále z jakých jednotlivých části a jakým způsobem se mají moduly skládat. Dále je vhodné určit, kdo bude kompetentní osobou zodpovědnou za kurzy, určené jednotlivým uživatelským skupinám. Výhodou mohou být také zkušenosti nabyté při př́pravě podobných kurzů. Každý kurz je obvykle sestaven z modulů, moduly z kapitol (optimum 3 až 7) a ty dle potřeby z podkapitol. Každá kapitola obsahuje prvky, které přináší nové poznatky a informace (informační text, mapa, apod.). Prvky jsou zpracovány vhodným způsobem mj. podle toho, pro jakou cílovou skupiny uživatelů je kurz určen. Dále se v kurzu vyskytují prvky motivační, verifikační a evaluační. Spojením všech prvkư pak vzniká funkční výukový model.

Obr. 2: Návrh struktury kurzu eklima pro vysoké školy (kliknutím na obrázek jej můžete zvětšit)

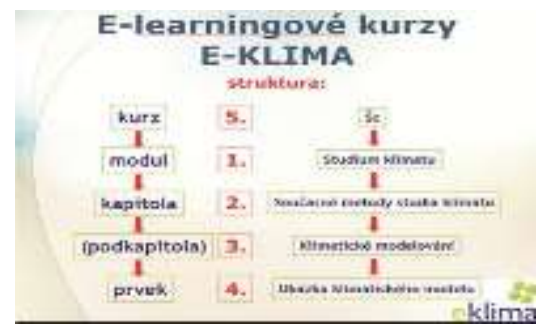

Výběr vhodného LMS (Learning Management System) jako výukové platformy

Prvním krokem bylo pojmové vymezení výukového systému a výběr vhodného systému. Výukový systém (Learning Management System, LMS) je v pravém slova smyslu 
rídicí výukový systém (systém pro řízení výuky), tedy aplikace řešící administrativu a organizaci výuky v rámci e-learningu (Ellis, 2009).

LMS jsou aplikace, které v sobě integrují zpravidla nejrůznější on-line nástroje pro komunikaci a řízení studia (nástěnka, diskusní fórum, chat, tabule, evidence, atd.) a zároveň zpřístupňují studentům učební materiály či výukový obsah on-line (kvíz, podcast) nebo off-line, tzn. materiály je možno/nutno stáhnout z výukového prostředí a pracovat s nimi nezávisle na svém zařízení (např. dokumenty ve formátu PDF) (Rice, 2008). Za běžné funkce systémů řízeného vzdělávání se považují různé nástroje, které jsou k dispozici jako dílčí softwarové části, jako např. evidence a správa kurzủ, správa studijních plánů, evidence hodnocení žáků, testování a přezkušování žáků, správa studijních plánů, komunikační nástroje, úložiště výukového obsahu atd. Pro všechny tyto funkce je důležitý požadavek na jejich přenositelnost a standardizaci. LMS jako celek by měl být otevřený a schopný snadno a rychle začlenit výukový obsah, vytvořený např́klad ještě před jeho zavedením.

K vlastnímu testování byly vybrány 4 systémy (eTutor, eDoceo, Moodle, LMS UNIFOR). Testovanými parametry byly:

- licenční politika - zda se jedná se o open-source projekt, který je šířen pod licencí GNU/GPL, a proto je možné jej bezplatně používat,

- požadavky systému - zda je systém kompatibilní se základními technologiemi serverů (Apache + PHP + mySQL),

- míra lokalizace do národního prostředí - zda je systém kompletně lokalizován, individuální výběr různých jazykových mutací je pro kompletní GUI,

- rozšířenost systému,

- požadavky na studenta - zda má systém příjemné a přehledné uživatelské rozhraní (mj. WYSIWYG editor), neklade zvláštní požadavky na počítačovou gramotnost a k jeho ovládání postačí základní dovednosti s PC,

- $\quad$ filozofie práce - zda systém podporuje aktivní účasti studentů na zadaných úkolech, přispívání do diskusních fór, účasti na hlasování, vyplnění online testů, vypracování písemné práce, studium přednášek apod.,

- $\quad$ zda Ize úkoly bodovat, což motivuje studenta k aktivní činnosti,

- $\quad$ zda a jak jsou oddělené role tvůrce kurzu a učitele kurzu,

- jak je možnost tvorby/editace kurzu z jakéhokoliv místa po autorizovaném přihlášení.

Jako nejkvalitnější byl vyhodnocen systém Moodle. Moodle je softwarový balík určený pro podporu prezenční i distanční výuky prostřednictvím online kurzů dostupných na internetu. Moodle je vyvíjen jako nástroj umožňující realizovat výukové metody navržené $v$ souladu $s$ principy konstruktivisticky orientované výuky. Umožňuje či podporuje snadnou publikaci studijních materiálů, zakládání diskusních fór, sběr a hodnocení elektronicky odevzdávaných úkolů, tvorbu online testů a radu dalších činností sloužících pro podporu výuky (Cole, 2007). Moodle je volně šiřitelný software s otevřeným kódem. Běží na platformách Unix, Linux, Windows, Mac OS X a dalších.

Pro specifické potřeby využití pro daný projekt docházelo k postupné úpravě funkcionality v závislosti na aktuálních požadavcích při naplňování kurzů. Podle toho, jak to jednotlivé úkoly $v$ systému vyžadovaly, byly softwarové části činností aktivovány či 
přidávány úplně nové. Z nových prvků přidaných speciálně pro daný projekt jsou to např. nové moduly testů, které zpřístupňují testové formy jako přiřazování obrázků, záměnu slov ve větě apod. Pro prezentaci studijních materiálů byl přidán prvek "kniha", který efektivněji prezentuje danou látku a umožňuje kombinovat text a multimediální prvky $v$ jedné úrovni.

\section{Obr. 3: Stránka s aktuálním přehledem kurzů (kliknutím na obrázek jej můžete zvětšit)}

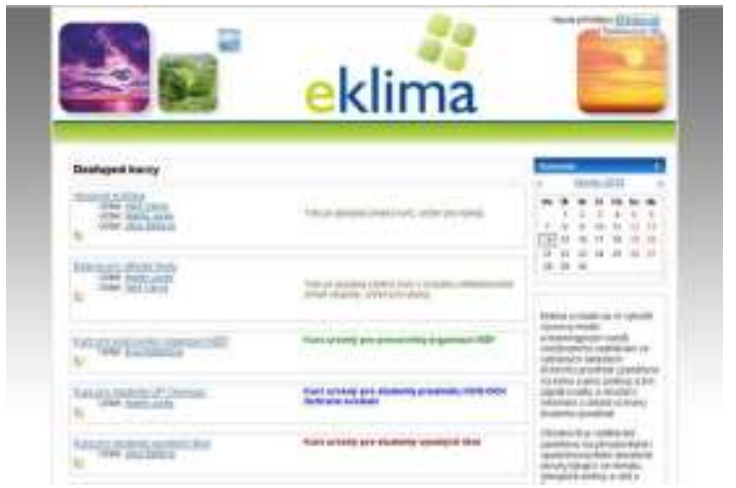

\section{Stanovení obsahu kurzů a jejich naplnění}

Souběžně s tvorbou výukového modelu a metodiky byl postupně nadefinován obsah kurzů, tj. bylo stanoveno, jaké konkrétní výukové moduly budou v kurzu zahrnuty a z jakých kapitol a podkapitol se mají skládat. Zde odborní garanti tématu "klima", „změna klimatu" a "globální oteplování z ČHMÚ a VŠE společně vytvořili osnovu pro e-learningový kurz určený pro vysokoškolskou skupinu studentů. Z tohoto kurzu byly posléze derivovány kurzy i pro ostatní cílové skupiny. Konkrétní osnova a moduly byly navrženy následovně:

- Klimatický systém

- Variabilita klimatu a jeho změn

- Dopady klimatické změny

- Příčiny problému, hnací síly

- Politika a nástroje

- Cesty řešení

$\mathrm{Na}$ začátku bylo navrženo šest kurzů pro různé skupiny uživatelů. Každý kurz obsahově odpovídá cílové skupině uživatelů, pro kterou byl sestaven. Nejprve byl založen obecný kurz, ten byl nazván vývojový. Tento kurz byl obsahově přizpůsoben vysokoškolské uživatelské skupině. $Z$ něho byly následně derivovány ostatní kurzy pro další cílové skupiny uživatelů. Tvorba jednotlivých kurzů probíhala systémem odvozování, zjednodušování nebo rozšiřování výukových materiálů a textů. $\vee$ průběhu naplňování vývojového kurzu byla dodržena základní navržená struktura kurzu. Při tvorbě obsahu autoři postupovali podle stanovené metodiky a pokynů pro autory. Ke všem vytvářeným prvkům byla pořizena metadata. Při odvozování kurzů určených pro střední a základní školy byla struktura přizpůsobena těmto uživatelským skupinám.

Dalším úkolem po vytvoření jednotlivých kurzů bylo převedení dodaných textů a materiálů do výukového prostředí a vytvoření funkčního obsahu e-learningových kurzů. 
Důležitým krokem bylo osvojení všech ovládacích prostředků a prvků, které nabízí výukové prostředí LMS Moodle ze strany tvůrců kurzu. Proběhlo stažení a studium tutoriálů, dokumentačních materiálů a návodů používané aplikace. Po úspěšném osvojení aplikačních nástrojů byly vytvořeny $v$ daném prostředí jednotlivé výukové prvky jako kniha, úkol, video, seznam zdrojů apod. Byly sestaveny šablony jednotlivých výukových prvků, po vytvoření šablon těchto prvků se přistoupilo $k$ samotnému převádění a naplňování obsahu jednotlivých kurzů. Při naplňování kurzů byly kromě klasických výukových materiálů, jako text, obrázky apod., využity i nové formy studijních materiálů jako jsou webové mapy, databáze, audiovizuální soubory a další.

\section{Obr. 4: Ukázková stránka kurzu (kliknutím na obrázek jej můžete zvětšit)}

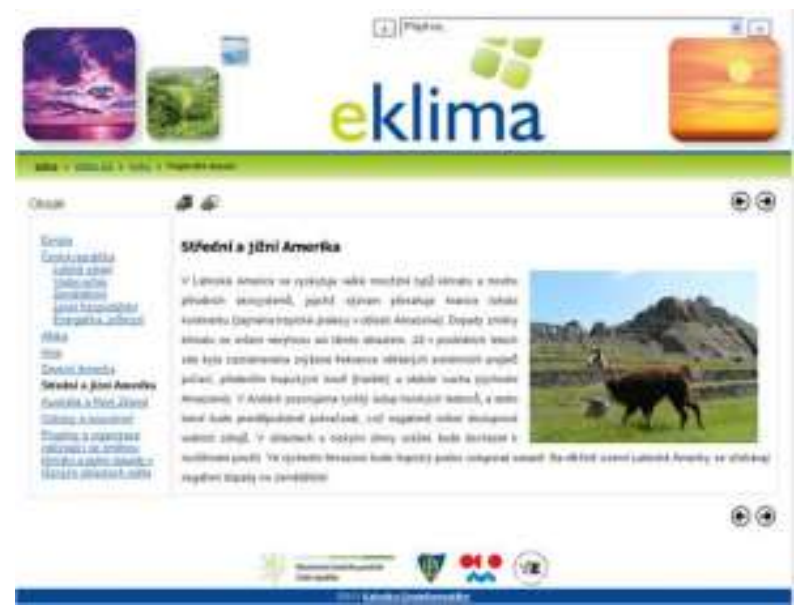

\section{Testování a vyhodnocení kurzů}

Po obsahovém naplnění kurzů přistoupil řešitelský tým projektu $k$ testování u předem vytipovaných vzorků cílových skupin. Celkově bylo vytvořeno šest různých kurzů pro jednotlivé testované skupiny uživatelů. Testování bylo uskutečněno v několika etapách. Nejdřive se uskutečnilo pilotní testování na menší skupině uživatelů (viz kap. 5.1.). Testovala se hlavně základní struktura a obsah kurzu (viz dtto). S ohledem na výsledky a připomínky uživatelů byl kurz opraven. Poté následovala druhá část testování (viz kap. 5.2.), do které byli zapojeni uživatelé ze všech cílových skupin, a ti si vyzkoušeli již opravené e-learningové kurzy. Zde byla sledována hlavně celková funkčnost všech částí kurzů. Poslední fáze představovala plné spuštění kurzů pro velké množství uživatelů ze všech cílových skupin.

Testování kurzů vždy probíhalo po stanovený časový interval (např. u studentů vŠ $v$ rámci semestrálního předmětu). Každý kurz byl veden tutorem, který zodpovídal za testování, představil kurz uživatelům, poskytoval podporu a na závěr vyhodnocoval kurz. Prostřednictvím tutora byli uživatelé na začátku seznámeni se základními prvky testování, jako jsou přístup ke kurzu, vytvoření uživatelského účtu, popis výukového prostředí kurzu, základní ovládací a navigační možnosti systému a technické požadavky na spuštění kurzu. Také byli seznámeni s časovou dispozicí a s požadavky, které budou muset při absolvování kurzu plnit. Toto seznámení probíhalo formou úvodních setkání. Pro studenty, kteří se nemohli zúčastnit, byl vypracován tutoriál obsahující potřebné informace. $V$ průběhu kurzu uživatelé testovali různé funkce, které systém nabízí, v př́ipadě otázek komunikovali s tutorem. Pokud se vyskytl problém, který nebyl schopen tutor vyřešit, kontaktoval tvưrce 
kurzu nebo administrátora systému, kteři poskytovali technickou podporu. Uživatelé v průběhu testování sdělovali své názory, připomínky a kritiky. Všechny ohlasy byly zaznamenávány k pozdějšímu vyhodnocení.

\section{První část testování (pilotní testování)}

Testovací skupinou byli vysokoškolští studenti bakalářského studia na Vysoké škole ekonomické $v$ Praze a dále testovací skupina uživatelů z oblasti veřejné správy, která obsahovala široké spektrum profesí různou měrou propojených s problematikou ochrany klimatu. Zahrnovala pracovníky veřejné správy z krajských a městských úřadů, ale také představitele ekologických a vzdělávacích institucí. Zkušenosti přihlášených účastníků s tématem klimatické změny a problematikou ovzduší před zahájením pilotního testování byly velice rozmanité, od žádných zkušeností přes informace získané z médií, seminářů na téma udržitelného rozvoje, až po zkušenosti ze samotného výkonu státní správy.

\section{Tab. 2 Počet proškolených v pilotním kurzu Veřejná správa}

\begin{tabular}{|l|l|}
\hline Přihlášených & 26 \\
\hline Zaregistrovaných ve webové aplikace eklima & 21 \\
\hline Úspěšně dokončilo & 13 \\
\hline
\end{tabular}

Tab. 3 Počet proškolených v pilotním kurzu Vysoké školy

\begin{tabular}{|l|l|}
\hline Přihlášených & 18 \\
\hline Zaregistrovaných ve webové aplikace eklima & 18 \\
\hline Úspěšně dokončilo & 15 \\
\hline
\end{tabular}

První fáze testování byla zaměřena na vyhledávání všech nedostatků a připomínek od jednotlivých účastníků kurzu. Hodnocení kurzu je nedílnou součástí všech kurzů, každému účastníkovi byla zaslána prosba o vyplnění dotazníku a poskytnutí zpětné reakce. $\mathrm{V}$ rámci dotazníkového šetření bylo sledováno hodnocení obsahu kurzu, tj. srozumitelnost materiálů pro danou cílovou skupinu, zda je po obsahové stránce náročnost studijních textů přiměřená, zda je správně nastavena výchozí úroveň znalostí, od které se daná problematika dále rozvíjí a prohlubuje, zda není obsah kurzu př́liš snadný nebo naopak př́liš náročný, nechybělo ani hodnocení celkové organizace kurzu a jeho webové aplikace.

Při pilotním ověření výukového kurzu eklima bylo na základě vyhodnocení dotazníků mezi účastníky zjištěno, že náročnost obsahu kurzu je přiměřená. Doplňujícími otázkami bylo zjištěno, že obsah kurzu byl z počátku spíše snadný a později naopak velmi náročný. Dalším důležitým hlediskem „uživatelské přivětivosti" výukového modelu i všech kurzů je srozumitelnost, a to nejen srozumitelnost obsahová, ale také srozumitelnost a přehlednost webové aplikace. Zatímco obsahová srozumitelnost byla účastníky pilotního ověření vyhodnocena kladně, se srozumitelností webové aplikace měli někteří z účastníků potíže. Tyto problémy byly identifikovány hlavně $v$ cílové skupině veřejné správy a vyhodnoceny jako nízká počítačová gramotnost některých účastníků. I s těmito skutečnostmi se nicméně při přípravě kurzu musí počítat, a právě proto jsou vydávány příručky pro uživatele a prưvodci studiem, které mají těmto problémům předcházet. Jako další opatření bylo zvoleno představení ovládání a funkčnosti webové aplikace na úvodním tutoriálu. 
Obr. 5: Vyhodnocení dotazníkového šetření pilotního projektu (skupina Veřejná správa) - náročnost obsahu kurzu, srozumitelnost obsahu kurzu a srozumitelnost webové aplikace (kliknutím každý obrázek můžete zvětšit)
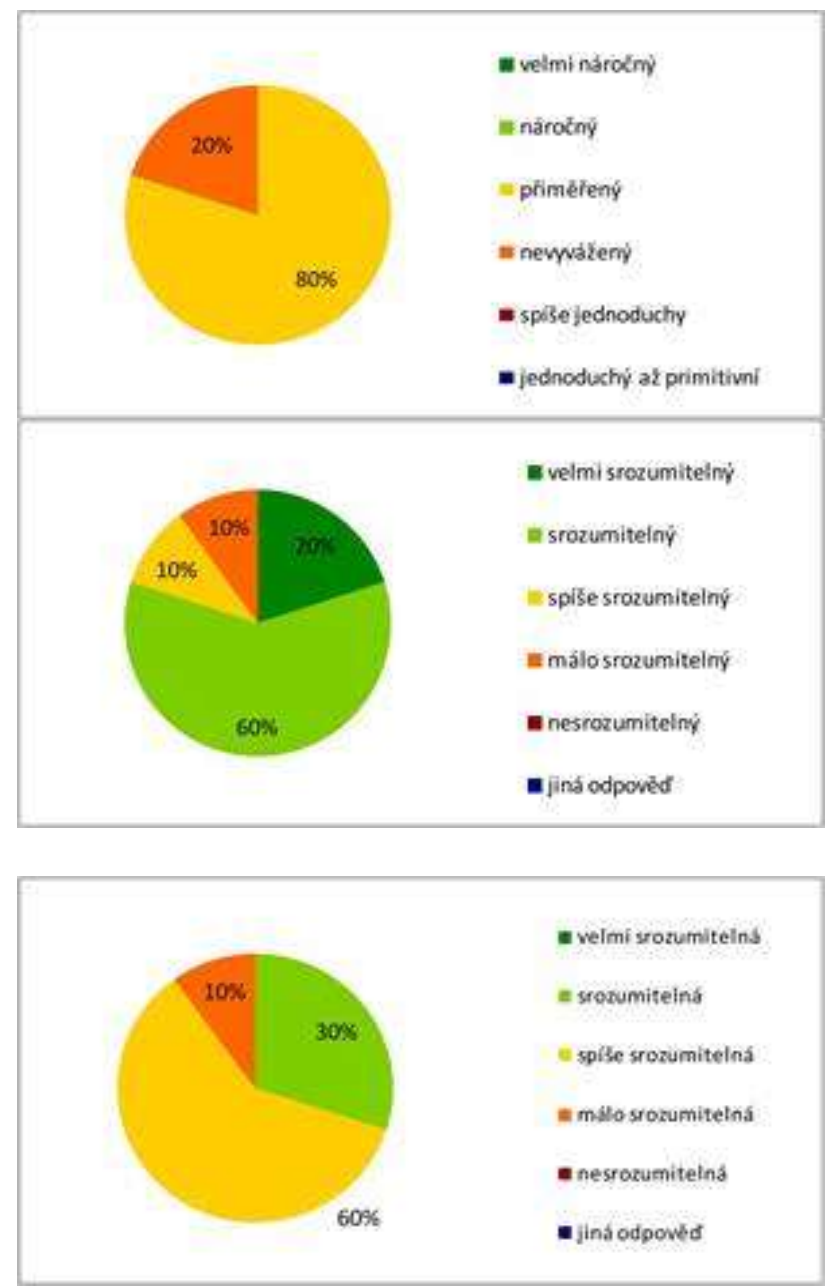

V průběhu testování byly posuzovány i další připomínky a nedostatky. $V$ první fázi testování kurzu se sešlo nejvíce připomínek. Ačkoli byl celý obsah oponován externími odborníky, autory textů a použité aplikace, uniklo několik menších nedostatků, které objevili až v průběhu pilotního nasazení dotyční uživatelé.

Po absolvování pilotních kurzů účastníci pozitivně hodnotili zajímavé téma a zajímavé informace, pestrost probírané tematiky. Kurz jim poskytl nové informace o tématu a rozšiřující pohled na ochranu ovzduší a prírody. V první fázi bohužel nefungovaly stoprocentně odkazy a obrázky připojené ve studijních materiálech, což byla jedna $z$ nejčastějších připomínek úvodního pilotního kurzu. Taktéž byly vzneseny připomínky k nevyváženosti testů jednotlivých kapitol, v prvních kapitolách bylo hodně úkolů typu testových otázek, zatímco v posledních kapitolách se zpracovávaly především odpovídací úkoly. Některé studenty délka úkolů a náročnost odradila od dokončení kurzu (počet odevzdaných úkolů se postupně velmi rychle snižoval).

Výsledkem prvního testování bylo také vytvoření podrobnější příručky k ovládání prostředí, protože zejména starší účastníci mívali občas s ovládáním prostředí a orientací 
ve výukovém prostředí problém. Příručka byla vytvořena tak, aby obsahovala nejdůležitější ovládací funkce a byla jednoduchá a přehledná. K vybraným tématům bylo vytvořeno několik otázek do diskuse, aby byli $v$ dalším cyklu účastníci motivováni diskutovat na vybraná témata.

\section{Druhá část testování (vyhodnocení upravených kurzů)}

Po první fázi pilotních kurzů byly zapracovány veškeré zjištěné připomínky. Připomínky se týkaly obsahu jednotlivých kapitol, a na jejich základě se upravovaly např. některá tvrzení nebo formulace, aktualizovala se data, odkazy, využívaly názornější grafy a doplňovaly některé informace. Úpravy však nebyly rozsáhlé. Došlo k úpravě koncepce kurzu ve verifikační oblasti, zejména aby se odstranila rozdílná náročnost jednotlivých kapitol, $v$ některých částech byl snižen počet otázek. Otázky a úkoly byly rovnoměrněji rozděleny do daného časového období.

Nově otevřený kurz byl tedy upraven zejména v následujících bodech:

Obsah kurzu

- $\quad$ snížení disproporce úkolů a testů

- snížení disproporce náročnosti jednotlivých úkolů

- odstranění opakujících se otázek

- aktualizace, úpravy překlepů

Organizace kurzu

- zlepšení komunikačního prostředí mezi studenty a lektory, snaha rozpoutat diskusi na webu

- vytvoření príručky pro ovládání prostředí

Webová aplikace

- zaručena funkčnost obrázků a odkazů před zahájením kurzu, celková prehlednost

- přepracovaný grafický design kurzů

- zvýšení přehlednosti (ne)splněných úkolů a testů

Druhé ověřování kvality studijních podkladů probíhalo znova na skupinách studentů VŠ a pracovníků veřejné správy. Testovací skupiny zahrnovaly jiné osoby, než se účastnily první fáze testování.

Tab. 4 Počet proškolených - veřejná správa

\begin{tabular}{|l|l|}
\hline Přihlášených & 21 \\
\hline Zaregistrovaných ve webové aplikace eklima & 19 \\
\hline Úspěšně dokončilo & 13 \\
\hline
\end{tabular}


Tab. 5 Počet proškolených - studenti vysokých škol celkově

\begin{tabular}{|l|l|}
\hline Přihlášených & 152 \\
\hline Zaregistrovaných ve webové aplikace eklima & 138 \\
\hline Úspěšně dokončilo & 135 \\
\hline
\end{tabular}

Ve druhém cyklu bylo pozitivně hodnoceno celkové rozšírení znalostí v oblasti klimatu a klimatické změny, objektivnost studijních podkladů, aktuálnost a komplexnost, užitečné odkazy na další literaturu a zdroje, perfektně zpracované studijní podklady, flexibilita a dobrá komunikace $\mathrm{s}$ organizátory. Někteři účastníci poukazovali na velké množství zpracovávaných úkolů, ale vzhledem k rozsahu kurzu je to pochopitelné. Někteří účastníci by zase přivítali větší množství studijních materiálů o legislativě. K webové aplikaci nebyly vzneseny již žádné zásadní připomínky

V této etapě testování byla sledována i celková úspěšnost plnění znalostních požadavků kurzu a úspěšnost odevzdaných úkolů. Z výsledků vyplývá, že pokud účastníci na otázky a úkoly odpoví, úspěšnost odpovědí je spíše vyšší. Přesto 30 až 40 \% testů a otázek zejména $v$ závěrečné části zưstalo nezodpovězeno.

Obr. 6: Zpětná vazba uživatelů $v$ rámci druhé fáze testování (skupina vš a veřejná správa) - srozumitelnost a náročnost kurzu, atraktivita a náročnost webové aplikace (kliknutím každý obrázek můžete zvětšit)

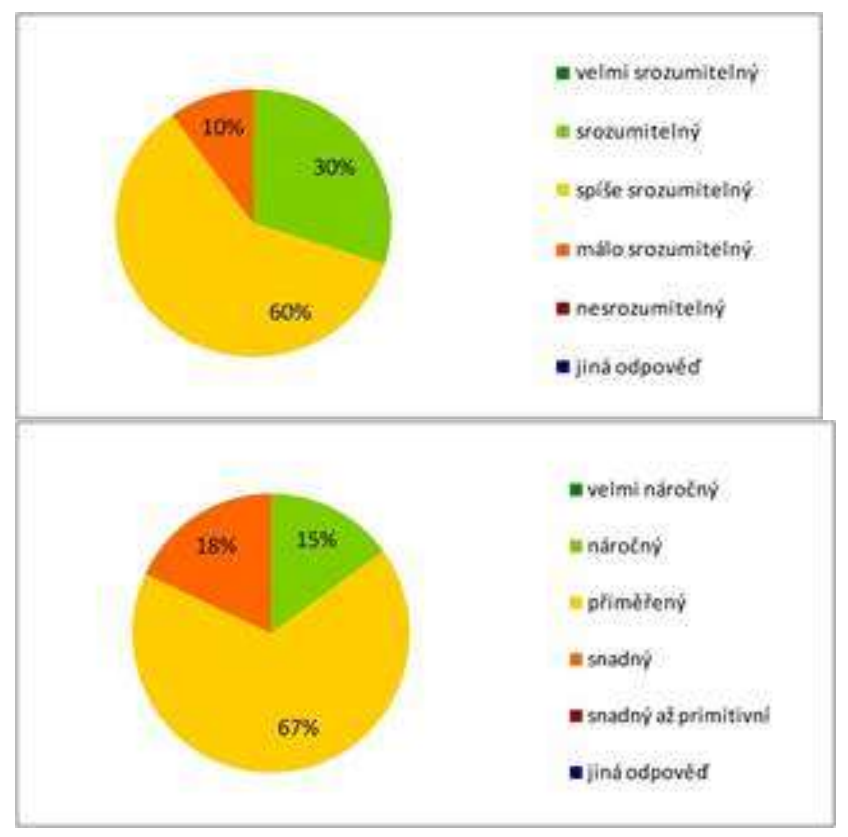




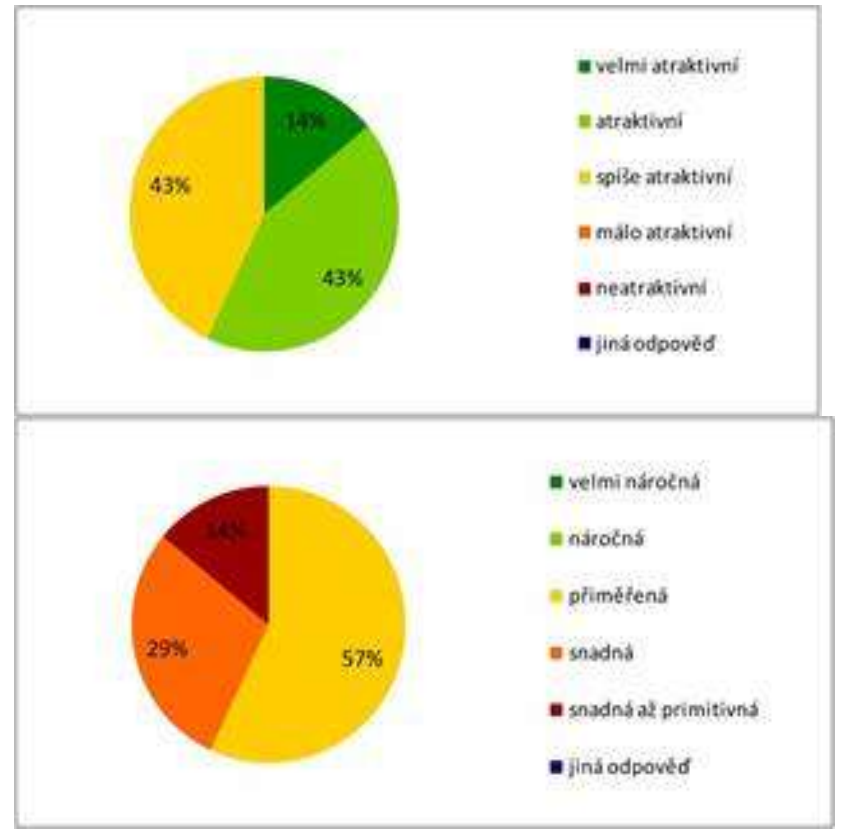

V této části se do testování zapojili také žáci středních a základních škol. Pro základní školy (2. stupeň ZŠ a nižší stupeň víceletých gymnázií) a pro střední školy byly vytvořeny dva rưzné e-learningové kurzy s různou úrovní podrobnosti a obtížnosti, avšak testování kurzů probíhalo v podobné koncepci jako pro ostatní skupiny uživatelư. Oba kurzy byly testovány na vybraných školách a gymnáziích za spoluúčasti zdejších pedagogů, a to především v rámci předmětů zeměpis nebo informatika (IVT - informační a výpočetní technika). Testování obou kurzů bylo potřeba přizpůsobit tematickému zařazení do učiva vybraných cílových skupin, a to na základě ŠVP (Školní vzdělávací program tvořený individuálně každou školou na základě RVP), případně v souladu s právě probíranou látkou.

V rámci dotazníkového šetření byly sledovány následující aspekty: hodnocení atraktivity kurzu, náročnost jednotlivých lekcí a kurzu jako celku, organizace kurzu a uživatelské prostředí. Zároveň bylo hodnocení vyžadováno i po učitelích, kteří se se svými žáky a studenty do testování zapojili. Tím byl zajištěn i pohled pedagoga, získány tedy byly dvě sady hodnotících formulářù.

Přiměřená náročnost odpovídá i úspěšnosti při vypracovávání průběžných a závěrečných testů - úspěšnost vypracování činila u kurzů pro základní školy v průměru 87 \% a u kurzů pro střední školy $92 \%$, přičemž pro hodnocení pod 80 \% bylo v hodnocení testu doporučeno účastníkům zopakovat si lekci a test vypracovat opakovaně.

Tab. 6 Úspěšnost vypracování průběžných a závěrečných testů - kurzy pro základní a střední školy

\begin{tabular}{|l|l|l|l|}
\hline & Účastníků & Uspěšných (nad 80\%) & Neúspěšných (pod 80\%) \\
\hline Kurz pro SŠ & 87 & 80 & 7 \\
\hline Kurz pro ZŠ & 65 & 56 & 9 \\
\hline
\end{tabular}

Hodnocení atraktivity kurzu dopadlo zcela jednoznačně - všichni respondenti dotazníkového šetření považují kurz za atraktivní a uživatelské prostředí za př́jemné. $\checkmark$ rámci organizace kurzu nebylo zvoleno hodnocení kvantitativní, ale byly sbírány 
konkrétní připomínky. Většina respondentů z řad účastníků základních i středních škol ocenila úvodní motivační hodinu, kde jim byl kurz eklima představen a motivační prezentací byly nastoleny problémové otázky, na něž kurz nabízí odpovědi (jak mưže klimatická změna ovlivnit život každého jedince, proč je důležité dbát na ochranu životního prostředí apod.). Většina respondentů přiznala, že v domácím prostředí kurzu věnovali méně času než ve škole, část účastníků však naopak domácí prostředí bez časového limitu ocenila s odůvodněním, že měli více času prostudovat si externí odkazy nebo videa.

Obr. 7: Vyhodnocení dotazníkového šetření v kurzech zš a sš - změny navrhované uživateli (kliknutím na obrázek jej můžete zvětšit)

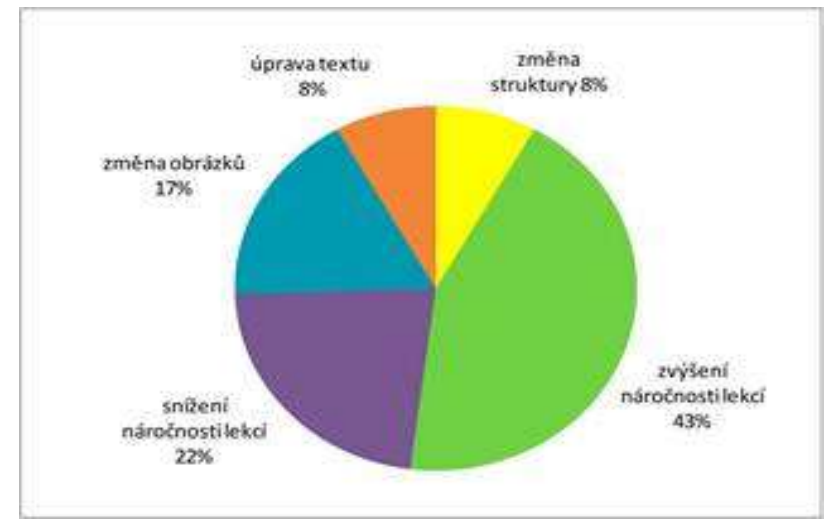

\section{Třetí část testování ( $p$ Iný provoz)}

Oproti první a druhé fázi, které byly testovací, měla třetí fáze charakter plného funkčního provozu kurzů. Samozřejmě zpětná vazba od účastníků byla opět součástí kurzu, ale cílem této fáze bylo proškolit co nejvíce účastníků.

V rámci vzdělávání studentů vysokých škol byl kurz nasazen na Vysoké škole ekonomické $v$ Praze, včetně studentů $z$ Fakulty managementu $v$ Jindřichově Hradci, a dále na Katedře geoinformatiky a geografie na UP $v$ Olomouci. Ze strany studentů byl o tématiku klimatu velký zájem, studenti měli před absolvováním kurzu o dané problematice pouze orientační znalosti a povědomí. Kurzu se účastnili studenti $\mathrm{z}$ bakalářských i magisterských programů, kurzy byly nasazovány $\mathrm{v}$ rámci různých předmětů. Studenti byli hodnoceni za účast $v$ kurzu a za úspěšné plnění dílčích i závěrečných úkolů. Jednalo se tedy o ostré nasazení, které prověřilo technickou i formální kvalitu vytvořených kurzů.

Tab. 7 Počet proškolených - veřejná správa

\begin{tabular}{|l|l|}
\hline Přihlášených & 22 \\
\hline Zaregistrovaných ve webové aplikace eklima & 24 \\
\hline Úspěšně dokončilo & 7 \\
\hline
\end{tabular}




\section{Tab. 8 Počet proškolených - studenti vysokých škol celkově}

\begin{tabular}{|l|l|}
\hline Přihlášených & 225 \\
\hline Zaregistrovaných ve webové aplikace eklima & 204 \\
\hline Úspěšně dokončilo & 188 \\
\hline
\end{tabular}

V rámci vzdělávání měli studenti možnost evaluace kurzu a možnost zasílání různých připomínek. Studenti tuto možnost využili, většina zaslaných připomínek byla kladného charakteru. Objevilo se několik negativních poznámek, které však nebyly vážnější povahy a byly téměř okamžitě vyřešeny. Zde jsou některé z nich i s řešením daného problému:

- Některé mapy a obrázky se nezobrazují - způsobeno nesprávným zadáním cesty k obrázku pomocí relativní adresy

- Delší texty splývají - vyřešeno proložením textů obrázky, tabulkami apod., př́padně bylo zvětšeno řádkování textu

- Aktuálnost některých informací - tento problém konzultován s garanty odborné části, texty byly znovu přečteny a aktualizovány ke konci roku 2010

- Na určité průběžné testy málo času - upraveno v nastavení testů, posunutí časového limitu na splnění testu

- Nemožnost tisku celé kapitoly - zde je povolen pouze výtisk jedné strany

Účelem této fáze testování bylo proškolit větší množství uživatelů než ve fázích předcházejících. Sledováno bylo především provozní zatížení serveru při větším počtu přistupujících účtů, dále samostatnost účastníků, v této části již nebyla tolik využívána postava tutora. Nakonec byly porovnány výsledky závěrečných testů, které ukazují, jakou má kurz schopnost přenést efektivně informace směrem ke studentovi. Všechny tyto sledované prvky měly pozitivní charakter. To znamená, že např. stabilita kurzu se projevila jako vynikající, v průběhu testování byl kurz neustále dostupný, zkušenosti lektorů s prací studentů v průběhu jednotlivých testovacích fází se zlepšovaly, díky zkušenostem se zlepšila komunikace a celková samostatnost uživatelů. Kurz byl nakonec vyhodnocen jako připravený k distribuci.

\section{Diskuze a závěr}

Výsledkem projektu jsou kompletní e-learningové kurzy, které mají za úkol zvýšit informovanost a gramotnost u vybraných skupin obyvatel ČR o tématech jako jsou zlepšení kvality ovzduší, podpora opatření na řešení problematiky změny klimatu a snižování emisí skleníkových plynů, opatření pro podporu udržitelného užívání zdrojů, kvalita a množství informací z oblasti ochrany životního prostředí a plnění Strategie udržitelného rozvoje.

Shromáždění dostupných informací o e-learningu, získání zdrojů informací, sestavení základních "stavebních" kamenů a analýza stávajících kurzů vedlo v průběhu projektu ke kvalitnímu sestavení výukového modelu a podle něho k vytvoření e-learningových kurzů. Kvalitní výukový model sestavený na základě výše uvedených předpokladů, vycházející z obecných didaktických pravidel, odborných poznatků a praktických zkušeností s e-learningovou výukou, je jediným možným východiskem pro realizaci kvalitního e-learningového vzdělávání širokého spektra uživatelů - od žáků základní školy po studenty univerzit i od běžného laika po uznávaného odborníka. 
Pokud e-learning má být efektivní, je nutné přizpůsobit jej cílové skupině uživatelů. $\checkmark$ prípadě projektu eklima bylo zvoleno několik rozdílných cílových skupin. Výukové materiály, ale i výukové prostředí, se musí přizpůsobit konkrétní uživatelské skupině. Např́klad pro žáky základních škol není vhodné $k$ výuce využívat případové studie, naopak resortním pracovníkům není vhodné jako úkoly zadávat obrázkové doplňovačky. Rozdíly jsou tedy $v$ náročnosti a objemu výukové látky, $v$ podobě jednotlivých výukových materiálù (text versus animace), v rozdílném designu výukového systému apod. Je logické, že uživatelé z řad vysokoškoláků budou mít náročnější kurz než středoškoláci, naproti tomu uživatelé $z$ veřejné správy a odborných institucí si budou vybírat ty kapitoly, které pro ně budou důležité a př́nosné a ocení zařazení prípadových studií vedle teoretických základů. Kurzy se od sebe liší také vzhledem. Jsou sice barevně jednotně sladěné, ale kurzy pro základní školy mají velká písmena a pestře zvýrazněná slova, a to hlavně kvůli vizuální atraktivitě pro žáky. Naopak odborníci ocení stř́dmější styl, který bude přehledný. Všechny tyto odlišné prvky jednotlivých kurzů byly otestovány zástupci uživatelských skupin a upraveny podle jejich reakcí (viz kapitola 5).

Během testovacího provozu se jako jeden z problémů kurzu ukázala jeho nevyváženost. Ta se projevila zejména $v$ rozdílné náročnosti jednotlivých modulů, v obsáhlosti, popisném stylu a různých formátech kontrolních úkolü. Některé kapitoly tak byly rozsáhlejší než jiné, testové otázky byly těžší a úkoly se skládaly z dlouhých odpovědí. Nevyváženost byla zpưsobena tím, že každou část vytvářeli jiní odborní garanti. To znamenalo, že první tři moduly byly odlišné od ostatních svým vyjadřovacím jazykem. Bylo tedy nutné pozměnit, sjednotit a vyvážit všechny kapitoly a moduly. Pokud by se tak nestalo, mohlo by to vést $\mathrm{k}$ roztřištění kurzu a uživatel by snadno ztrácel pozornost a motivaci. Kurzy byly tedy znovu přečteny odbornými garanty i nezávislými osobami a následně upraveny. Nutno podotknout, že tento problém se týkal pouze vysokoškolských a resortních kurzů.

Hlavní výhodou kurzů je shromáždění a poskytnutí informací zabývajících se klimatem Země a jeho změnou. Informace jsou podávány nejen formou textu, ale je využito mnoho dalších aktivačních, motivačních i verifikačních prvků. Obsahová správnost je zajištěna odbornými garanty. Výukové kurzy jsou vytvořeny $v$ systému, mezi jehož výhody patří dostupnost, jednoduchost a stabilita. Kurzy jsou sestaveny pro několik skupin uživatelů, od žáků základních škol až po resortní pracovníky. Pro každou uživatelskou skupinu je stanovena př́slušná náročnost. E-learningové kurzy $\mathrm{s}$ danou tematikou jsou moderní výukovou podporou a mají potenciál stát se vhodnou pomůckou pro (celoživotní) vzdělání v mnoha školách a institucích.

\section{Poděkování:}

Příspěvek vznikl $v$ rámci projektu VaV Ministerstva životního prostředí ČR pod registračním číslem SPII/4h6/35/07 Výukový model e-learningu pro celoživotní vzdělávání ve vybraných oblastech ŽP (e-klima). 


\section{Literatura}

- Baumgartner, P. (2004) The Zen Art of Teaching - Communication and Interactions in eEducation. In Proceedings of the International Workshop ICL2004. Villach: Kassel University Press.

- $\quad$ CEC - Commission of The European Communities, Communication from the Commission to the council and the European Parliament, The eLearning Action Plan: Disigning tommorow's education, $\operatorname{COM}(2001) 172$, Brussels, 28.3.2001, s. 2. . .

- Cole, J., \& Foster, H. (2007). Using Moodle: Teaching with the Popular Open Source Course Management System. Beijing: O'Reilly Media.

- Eger, L. (2005) Motivace v e-learningu. In E-learning forum (pp. 1-9). Praha: ECON publishing.

- Ellis, R. K. . Field Guide to Learning Management Systems. ASTD Learning Circuits. . Retrieved from http://www.astd.org/NR/rdonlyres/12ECDB99-3B91-403E9B157E597444645D/23395/LMS fieldguide 20091.pdf

- Ghil, M. (2002) The Earth system: physical and chemical dimensions of global environmental change. In Encyclopedia of Global Environmental Change (pp. 544-549). Chichester: John Wiley \& Sons.

- Intergovernmental Panel on Climate Change (IPCC), (2007). Fourth Assessment Report. The Physical Science Basis. : Cambridge University Press.

- Intergovernmental Panel on Climate Change (IPCC), (2010). WGI Contribution to IPCC Fifth Assessment Report. . Retrieved from http://www.ipcc-wg1.unibe.ch/AR5/chapteroutline.html

- Květoň, K. (2005). Úloha e-learningu na školách. Ostrava: Ostravská univerzita v Ostravě.

- Nichols, M. (2003). A theory for eLearning. Educational technology \& society, 6(2), 1-10.

- Nocar, D. a kol., (2004). E-learning v distančním vzdělávání. Olomouc: VUP.

- Noll, C. L., \& Wilkins, M. (2002). Critical skills of IS professionals: A model for curriculum development. Journal of information technology education, 1(3), 143-156.

- Encyclopedia of World Climatology (2005). : Springer.

- Pechanec, V., Štávová, Z., \& Voženílek, V. (2007) Blended learning ve výuce tematické kartografie. In Súčasné trendy $v$ kartografii - Zborník referátov 17. kartografickej konferencie. Bratislava.

- Pechanec, V., Vávra, A., Voženílek, V., Tolasz, R., Jílková, J., Němcová, Z., Šeflová, J., Holtanová, E., Vondráková, A., Jurek, M., (2010) Education Project About Climate for MultiUser eLearning Courses. In P. Escudeiro (Ed.), Proceedings of the 9th European Conference on e-Learning (pp. 454-462). Reading: Academic Publishing Limited.

- $\quad$ Rice, W. (2008). Moodle 1.9 E-Learning Course Development: A complete guide to successful learning using Moodle 1.9. : Packt Publishing.

- Salmon, G. (2002). E-tivities. The Key to Active Online Learning. London: Tayler \& Francis.

- Unfcc, (2010). United Nations Framework Convention on Climate Change. . Retrieved from http://unfccc.int

- Van Ierland, E.,, , Gupta, J., \& Kok, M. (2003). Issues in International Climate Policy: Theory and Policy. illustrated edition.. Cheltenham: Edward Elgar Publishing.

- Vaněk, J. (2008). E-learning, jedna z cest k moderním formám vzdělávání. Karviná: Slezská univerzita v Opavě, Obchodně podnikatelská fakulta. 
- Vávra, A., Pechanec, V., Voženílek, V., Němcová, Z., \& Šefová, J. (2009). Aspekty tvorby elearningových kurzů na príkladu portálu e-klima. E-Pedagogium,5, 122-142.

- VŠEtUlovÁ, M. a kol., (2007). Př́ručka pro tutora. Olomouc: Univerzita Palackého v Olomouci.

- White, B., Tastle, W., \& Fox, D. (2003). Barriers to E-Learning in Information Systems. In The Proceedings of ISECON 2003. San Diego: Foundation for Information Technology Education.

- Zlámalová, H. . Distanční vzdělávání a eLearning : Učební text pro distanční studium. Praha: Univerzita Jana Amose Komenského Praha. 
Časopis Envigogika vydává Centrum pro otázky životního prostředí UK. Vývoj časopisu je podpořen projektem OP VK Mezioborová sít udržitelného rozvoje.

Více najdete na internetových stránkách projektu mosur.czp.cuni.cz
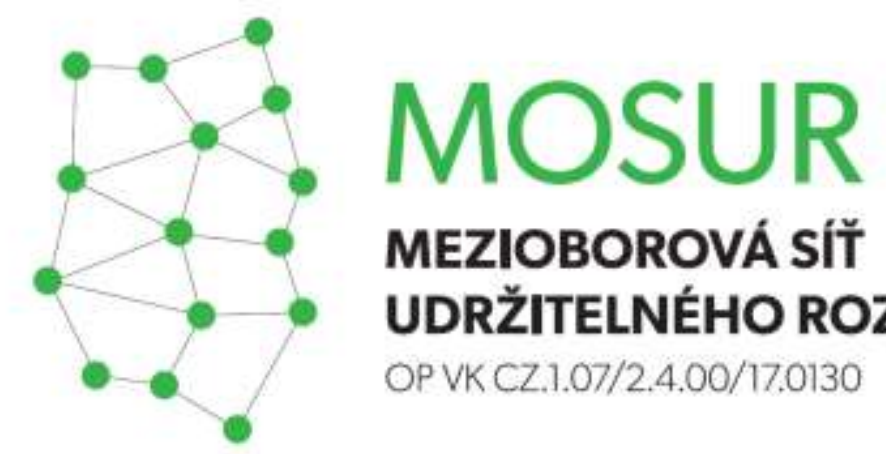

\section{MEZIOBOROVÁ SÍT} UDRŽITELNÉHO ROZVOJE

OP VK CZ.1.07/2.4.00/17.0130
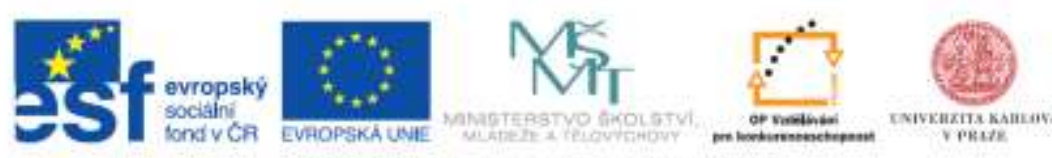

INVESTICE DO ROZVOJE VZDELAVANI 